\section{Effects of self-produced compost and biochar amendments on mobility and uptake of metals and metalloids in moderately contaminated soil of an allotment garden}

\author{
ALICE KOHLI $^{1,2,3}$, LILIANE JEAN-SORO ${ }^{1}$, RENÉ \\ GUÉNON $^{2}$ AND LAURE VIDAL-BEAUDET ${ }^{2}$ \\ ${ }^{1}$ Université Gutave Eiffel \\ ${ }^{2}$ Institut Agro - Agrocampus ouest \\ ${ }^{3}$ IRSTV
}

Presenting Author: alice.kohli@univ-eiffel.fr

Compost application can potentially reduce trace metals and metalloids (TMM) mobility in contaminated soils and their uptake by vegetables by altering $\mathrm{pH}$ and increasing sorption capacity. However, the effects of self-produced composts on TMM remain weakly understood because of their great diversity regarding to biogeochemical properties and rates of application used by gardeners. The aim of this study was to analyze 60 selfproduced composts and select five contrasted composts by elemental composition and biochemical properties. These composts were used to conduct experiments on lettuce grown in pots filled by soil moderately contaminated by lead $(\mathrm{Pb} ; 106$ mg. $\left.\mathrm{kg}^{-1}\right)$. A standardized compost used as reference (R), two gardener's composts (G1 and G2), a municipal green waste compost (MGW) and a collective food waste compost (CFW) were applied at 100 and 200 t.ha $^{-1}$ i.e. 3.3 and $6.6 \%$ dry weight (dw). MGW was also applied at 25, 50, 150 t.ha $^{-1}$ to look closer into a dose effect. A biochar (B) was also tested alone at 10, 30, 100 t.ha ${ }^{-1}$ or co-added at 30 t.ha $^{-1}$ with CFW at 100 t.ha $^{-1}$ to test its sorption capacity. The TMM concentrations were monitored in soil pore water during 60 days and in lettuce after 35 days of growth. First results showed that $\mathrm{CFW}, \mathrm{R}$ and $\mathrm{G} 1$ additions immediately increased trace elements concentrations in soil pore water with 100 t.ha ${ }^{-1}$ and more with 200 t.ha ${ }^{-1}$. CFW application at 200 t.ha $^{-1}$ especially increased $\mathrm{Pb}, \mathrm{Cd}, \mathrm{Cu}$ and $\mathrm{As}$ concentrations by $10,5,4$ and 3 fold compared to non-amended soil, reaching 3.4, 0.32, 134 and $36 \mu \mathrm{g} . \mathrm{L}^{-1}$, respectively. Overall, $\mathrm{Pb}$ uptake in lettuce was higher in particular for soil amended with $200 \mathrm{t}^{\mathrm{h}} \mathrm{ha}^{-1}$ of MGW $\left(0.65 \mathrm{mg} \cdot \mathrm{kg}^{-1} \mathrm{dw}\right)$ and $100 \mathrm{t}^{-h^{-1}}$ of CFW (0.64 mg.kg $\left.{ }^{-1} \mathrm{dw}\right)$ compared with non-amended soil $(0.33$ mg. $\left.\mathrm{kg}^{-1} \mathrm{dw}\right)$. Arsenic uptake was higher in particular with 200 t.ha ${ }^{-1}$ of CFW (0.28 mg.kg $\left.{ }^{-1} \mathrm{dw}\right), \mathrm{MGW}\left(0.28 \mathrm{mg} \cdot \mathrm{kg}^{-1} \mathrm{dw}\right), \mathrm{G} 1$ $\left(0.26 \mathrm{mg} \cdot \mathrm{kg}^{-1} \mathrm{dw}\right)$ and $\mathrm{R}\left(0.18 \mathrm{mg} \cdot \mathrm{kg}^{-1} \mathrm{dw}\right)$, compared with nonamended soil $\left(0.12 \mathrm{mg} \cdot \mathrm{kg}^{-1} \mathrm{dw}\right)$. This study suggests that amendment by self-produced and also standardized composts of contaminated allotment garden could mobilize TMM and increase their uptake.

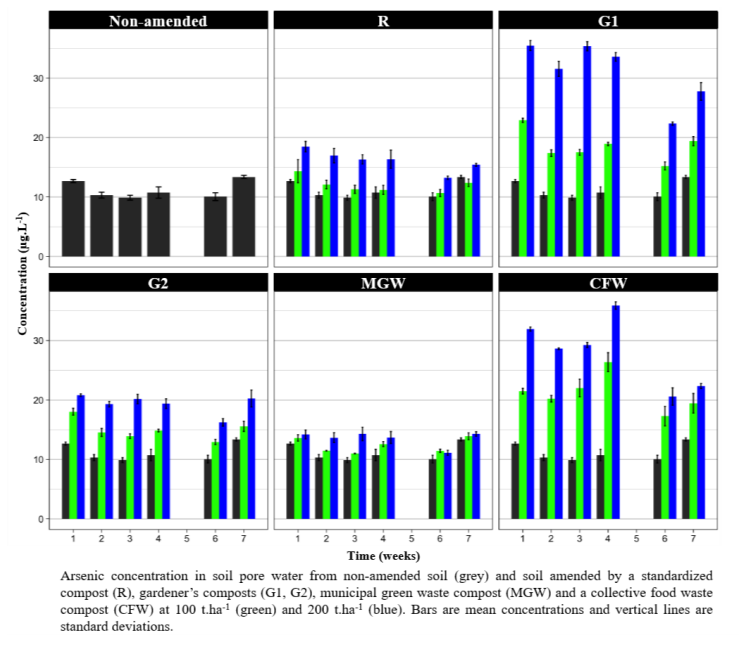

